\title{
Uses of Local Plant Species by Agropastoralists in South-western Niger
}

\author{
Augustine Abioye Ayantunde, Pierre Hiernaux, \\ Mirjam Briejer, Henk Udo, Ramadjita Tabo
}

Research

\begin{abstract}
Knowledge pertaining to local plant species in West African Sahel has been poorly documented despite the central role local vegetation plays in the everyday lives of the rural people. An ethnobotanical study was conducted between April and November 2005 to document knowledge and uses of local herbaceous and woody species by the agropastoralists in South-western Niger. One hundred and twenty three voucher reference samples were collected consisting of 87 and 36 herbaceous and woody species, respectively. The voucher specimens were used for individual interviews of the agropastoralists, guided by a semi-structured questionnaire. In each interview session, an interviewee was shown voucher reference samples and was asked to identify each of them. For each plant species identified, questions were asked about its utilization and the plant part(s) being used. Major uses of local plant species are for traditional medicine, human consumption, animal feed, household construction and firewood. Mean use value of woody species was significantly higher for all use categories $(p<0.001)$ than for the herbaceous species. These results confirm that "apparent" plants, perennial woody species, are used by the agropastoral communities more intensively than the "non-apparent" short life cycle herbaceous species.
\end{abstract}

\section{Introduction}

In West African Sahel, local vegetation has a central role in the everyday lives of rural people. Local vegetation provides people with food, fuel and medicine, as well as materials for construction and the manufacturing of crafts and many other products (Hamilton et al. 2003). Harvesting and processing of various plant products are undertaken by rural people in the region to fulfill their various daily needs (Nikiema 2005). Most rural populations in the Sahel will continue to be heavily reliant on local wild plants in the foreseeable future. Apart from man's reliance on plant products, livestock also depend mainly on local vegetation for their feed. Given the long history of interactions between the local people and their environment, there undoubtedly exists an extensive local knowledge on plants and their uses.

In order to understand the contributions of the local plant species to the socio-economic and cultural conditions and overall livelihoods of the rural communities, and the appropriate strategies to sustainably manage these resources, the value of individual plant species overall and for specific uses need to be determined. Quantitative ethnobotanical techniques have been used to describe the importance of trees to local people and to compare the importance of different species (Phillips \& Gentry 1993a,b, Theilade et al. 2007). In addition to its descriptive goals, quantitative ethnobotany makes use of numerical data that can be analyzed statistically. The use-value technique is a quantitative ethnobotanical approach proposed by Phillips and Gentry (1993a,b) as a measure of the relative importance of a plant. This technique is based

\section{Correspondence}

Augustine Abioye Ayantunde, International Livestock Research Institute, ILRI/ICRISAT, B.P. 320, Bamako, MALI.

a.ayantunde@cgiar.org, ayantunde@hotmail.com

Pierre Hiernaux, Centre d'Etudes Spatiales de la Biosphère (CESBIO), 18 avenue Edouard Belin, bpi 2801, F - 31041 Toulouse Cedex 4, FRANCE.

Mirjam Briejer and Henk Udo, Animal Production Systems Group, University of Wageningen, P.O. Box 338, $6700 \mathrm{AH}$ Wageningen, THE NETHERLANDS.

Ramadjita Tabo, International Crops Research Institute for the Semi-Arid Tropics (ICRISAT), B. P. 12404, Niamey, NIGER.

Ethnobotany Research \& Applications 7:053-066 (2009)

Published: April 10, 2009 
on the number of uses attributed to a plant by the totality of informants. Plants that are infrequently mentioned will therefore be considered as less valued. The major weakness of this technique is that it does not distinguish between 'real use' and 'knowledge' or 'cognitive use' (Albuquerque \& Lucena 2005). In addition, the use-value technique does not consider the cultural significance of a plant, its frequency of use or exploitation, nor the conduct of the local people in relation to the plant. In this study, we used the use-value technique to determine the relative importance of both woody and herbaceous plant species in the study location. The use-value technique was chosen as it is considered objective, reproducible and appropriate for statistical analyses (Hoffman \& Gallaher 2007).

Several ethnobotanical studies in arid and semi-arid regions in Africa (Diop et al. 2005, Kiringe 2006, Lykke et al. 2004, Nikiema 2005, Theilade et al. 2007) and in similar regions in the rest of the world (Albuquerque et al. 2005, Ladio et al. 2007) have emphasized the relative importance of woody plant species in the livelihoods of local communities. These studies failed to consider the importance of herbaceous species which form a key component of arid and semi-arid vegetation and a major source of forage for animals. Hence, in this ethnobotanical study the herbaceous plants were included along with the woody plants.

This study documents knowledge of local uses of herbaceous and woody plant species by the agropastoral communities in South-western Niger. The effects of ethnicity, gender and age on indigenous knowledge of the local plant species in the study site have been considered in a separate paper (Ayantunde et al. 2008). By using usevalue technique, we tested the "apparency" hypothesis postulated by Phillips and Gentry (1993a,b), that a plant's visibility tends to affect its local use. This implies that 'apparent' plants which are usually perennial woody plants or those that are normally dominant in the ecosystem will tend to have a higher relative importance in terms of use than 'non-apparent" plants, mostly herbaceous species with a short life cycle (Albuquerque \& Lucena 2005). The objective of this study was to document local knowledge on utilization and relative importance of herbaceous and woody plant species in South-western Niger and to explore strategies used for community-based management of these resources. This study was carried out under the Desert Margins Program (DMP) project on arresting land degradation and the conservation of biodiversity in the desert margins of sub-Saharan Africa, partly funded by Global Environment Facility (GEF).

\section{Materials and Methods}

\section{Study Site}

The work presented here was conducted from April to November 2005 in three agropastoral territories namely
Banizoumbou, Tigo Tegui and Kodey in the Fakara region of South-western Niger (Kollo District). The study area is situated between the confluent valleys of the Niger River to the west and fossil valley of the Dallol Bosso to the east $\left(13^{\circ} 20^{\prime}-13^{\circ} 35^{\prime} \mathrm{N} ; 2^{\circ} 35^{\prime}-2^{\circ} 52^{\prime} \mathrm{E}\right)$. The area has been described in detail by Turner and Hiernaux (2002). The climate of Fakara is a typical inland semi-arid tropical climate with an average annual rainfall of $560 \mathrm{~mm}$ (1905 to 1989; Lebel et al. 1997). Fakara is part of the central Sahel bio-climatic zone. Rainfall is strictly monomodal, falling mostly between July and October. The study site covered $500 \mathrm{~km}^{2}$ and is populated mainly by the Djerma and Fulani ethnic groups. In 1998, the population of the study site was 6000 inhabitants (Hiernaux \& Ayantunde 2004). The three agropastoral territories where the survey was conducted are experiencing different land use pressures with Kodey having a high proportion of land cropped $(65 \%$ in 1996) compared to $25 \%$ and $39 \%$ for Banizoumbou and Tigo Tegui, respectively (Turner \& Hiernaux 2002). The vegetation of the study site is composed of two main components: an herbaceous layer dominated by long cycle annual grasses, and a scattered population of small trees and shrubs (Hiernaux \& Ayantunde 2004). Unlike other arid ecosystems, perennial grasses and under-shrubs are not common. The severity and long duration of the dry season inhibits perennial grasses, while the seasonal regularity of the rains favors annual plants.

\section{Ethnic groups in the study site}

Djerma and Fulani are the two ethnic groups found in Fakara, our study site. The Djerma is the second largest ethnic group in Niger (about $21 \%$ of the total population), following the Hausa. The Djerma are historically land cultivators and their rural economy is largely dominated by subsistence agriculture. The main crops grown on their fields, usually controlled by a male household head, are millet (Pennisetum glaucum (L.) R.Br.), sorghum (Sorghum bicolor (L.) Moench) and cow pea (Vigna unguiculata (L.) Walp.). On individual fields the Djerma women grow groundnut (Arachis hypogaea L.), various kind of vegetables and, on the banks of the river Niger, wet rice (Oryza sativa L.). Though predominantly farmers, many Djerma own small herds of cattle, sheep and goats. During the growing season, the animals of the Djerma are generally given to Fulani herdsmen who take care of them against payment in kind or in exchange of land. The Djerma form the majority of the population in Fakara and they largely control land ownership (Turner \& Hiernaux 2002).

Fakara also harbors a significant number of Fulani people, who are pastoralists but are increasingly engaged in farming. The Fulani ethnic group accounts for about $10 \%$ of Niger's total population (Vennemann 2000). The Fulani are distributed all over the country. They are traditionally livestock keepers complemented by subsistence production of millet and sorghum. Keeping cattle is prestigious for the Fulani. In Fakara, the Fulani have settled in camps 


\section{Ayantunde et al. - Uses of Local Plant Species by Agropastoralists in South- western Niger}

in the vicinity of Djerma villages. They account for about $20 \%$ of the population in the study site (Turner \& Hiernaux 2002). In addition to livestock rearing, many Fulani in Fakara grow crops (mainly millet and cow pea).

\section{Ethnobotany Survey}

Voucher specimens of herbaceous and woody species in Fakara were collected between September and October 2004 by a research technician who has been conducting vegetation surveys in the study site since 1994 . To ensure collection of as many plant species as could be found in the study site, the research assistant was accompanied by a local guide who is highly knowledgeable of the local vegetation. One hundred and twenty three plant species were collected consisting of 87 herbaceous and 36 woody plant species. In view of inter-annual fluctuations in floristic composition that normally characterize annual dominated Sahelian vegetation (Hiernaux \& Ayantunde 2004), a few annual herbaceous species may have been left out in our collection. However, we believe that the number left out was small, and would not have altered our data significantly. The year we collected the voucher specimens (2004) actually had quite a high number of annual herbaceous species (87) compared to the average of 72 species recorded from vegetation surveys of the study site between 1994 and 2003 (Hiernaux \& Ayantunde 2004). The resulting herbarium was used for the interviews which were conducted individually. The interviews were guided by a semi-structured questionnaire. In each interview session, an interviewee was shown plant species collected and was asked to identify each of them. Mentioning of the correct local name(s), either in Zarma (Djerma's language) or Fulfulde (Fulani's language) of a plant species by the interviewee was considered as a correct identification of the plant. We followed the dictionary of local names of plants in Niger by Peyre de Fabregues (1977). This dictionary contains the vernacular names of most herbaceous and woody plant species in Niger for all the major languages (Hausa, Zarma, Fulfulde and Tamacheq). In our study site, the two major languages are Zarma and Fulfulde and the dictionary of local plants in Niger by Peyre de Fabregues provides vernacular names for all the plant species we used for the interviews. In all the interviews we did not come across new vernacular names for any of the species. For each plant species that was identified by the interviewee, questions were asked about use and the plant parts being used, habitat and perception on the present population status (species abundance) of the plant species. For plant uses, six use categories were included namely medicine, food, forage, construction, firewood and others. Uses of plants for household utensils, farm tools, magic, ornaments and decorations, and burial were included in the category "other". A question on the habitat focused on where the plant species are normally found. On the perception of present population status of the plant species, we asked if the species is abundant, moderately available, rare or has disappeared. The sci- entific names of plants species follow Hutchinson and Dalziel (1954-1972) Flora of West Tropical Africa unless revised since that time.

Two hundred and five respondents were interviewed from 2 dominant ethnic groups (Djerma and Fulani) representing about $5 \%$ of the population. The informants included 116 male (age 16-65 years) and 89 female (14-71 years) Three male enumerators who were fluent in the languages of the interviewees (Fulfulde and Zarma) administered the questionnaire.

\section{Data Analysis}

A use-value (UV) was calculated for each species, and use-category employing the following equations (Lucena et al. 2008):

$U V=\sum U i / n$, and UVc $=\sum U V / n c$

Where: $\mathrm{Ui}=$ number of uses mentioned by each informant; $n=$ total number of informants; $U V c=$ use value of each species in the use category; $\mathrm{nc}=$ number of species in the use category.

Data analysis was performed with SAS (1987) using a frequency procedure for the description of the data. ANOVA procedure in SAS was used to analyze use-value data for different use categories per plant types (herbaceous and woody plant species). Differences among the use categories were compared using Tukey's Studentized Range Test (HSD) in the ANOVA statement. Differences between the two plant types (herbaceous versus woody plant species) were compared using T-Test. Unless otherwise specified, the level of significance was declared at $p<0.05$.

\section{Results}

\section{Relative importance of plant species based on use-value}

Of the 87 herbaceous plant species included in the survey, 81 were considered useful, whereas all 36 woody plant species were considered useful by the respondents. The species were placed in six use categories. Figure 1 indicates the species richness reported for herbaceous and woody plant species. For the woody plants, nearly all the species were reported to be useful for medicine, forage, construction and firewood. The number of uses per species ranged from 1 to 5 (Figure 2). Nearly $60 \%$ of the herbaceous species had one use, mainly as forage whereas about $80 \%$ of the woody plants in the study site had at least 3 uses (Figure 2). The use-values for all the use categories within each plant type (herbaceous and woody species) were significantly different (Table 1). For all use categories woody plants had significantly higher use-values than the herbaceous plants (Table 1). Nine 


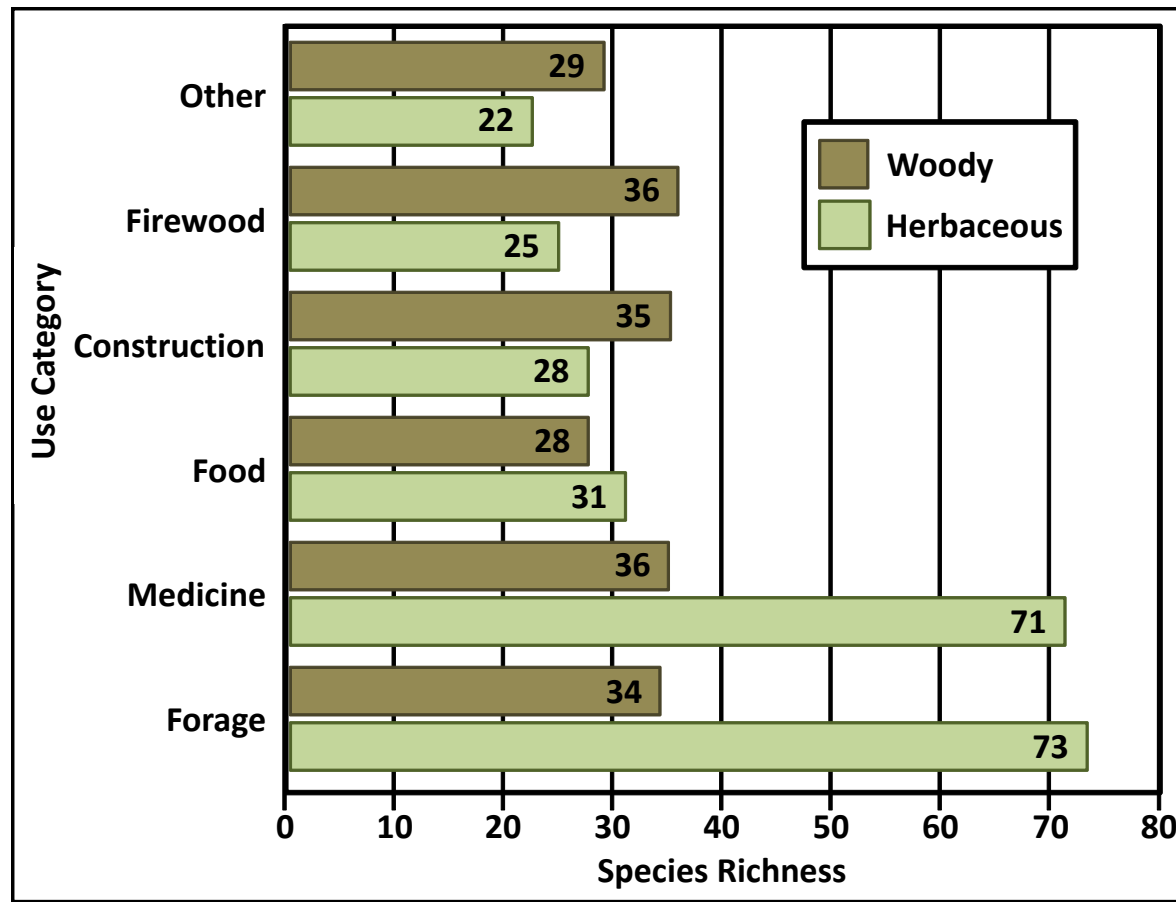

Figure 1. Distribution of species richness by plant type in the different use categories reported by agropastoralists in South-western Niger.

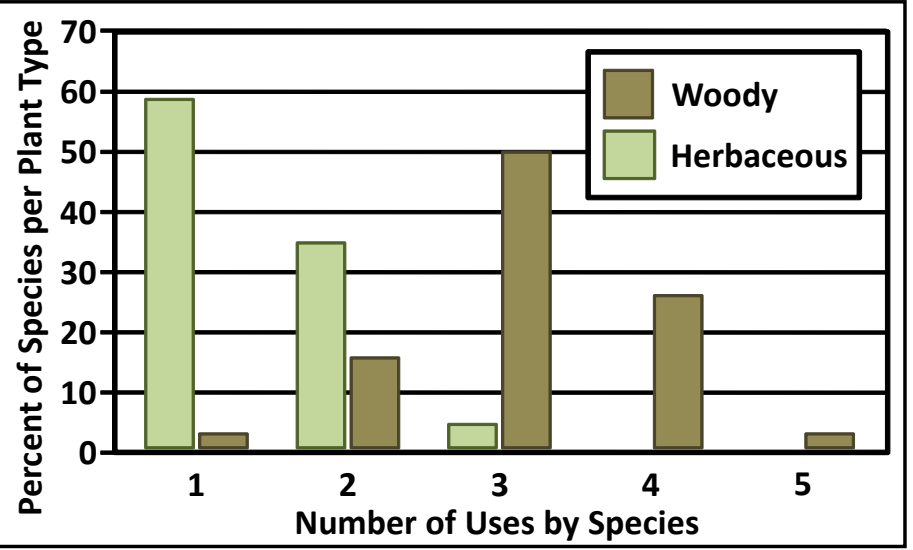

Figure 2. Number of uses attributed to each species by plant type as reported by agropastoralists in South-western Niger.

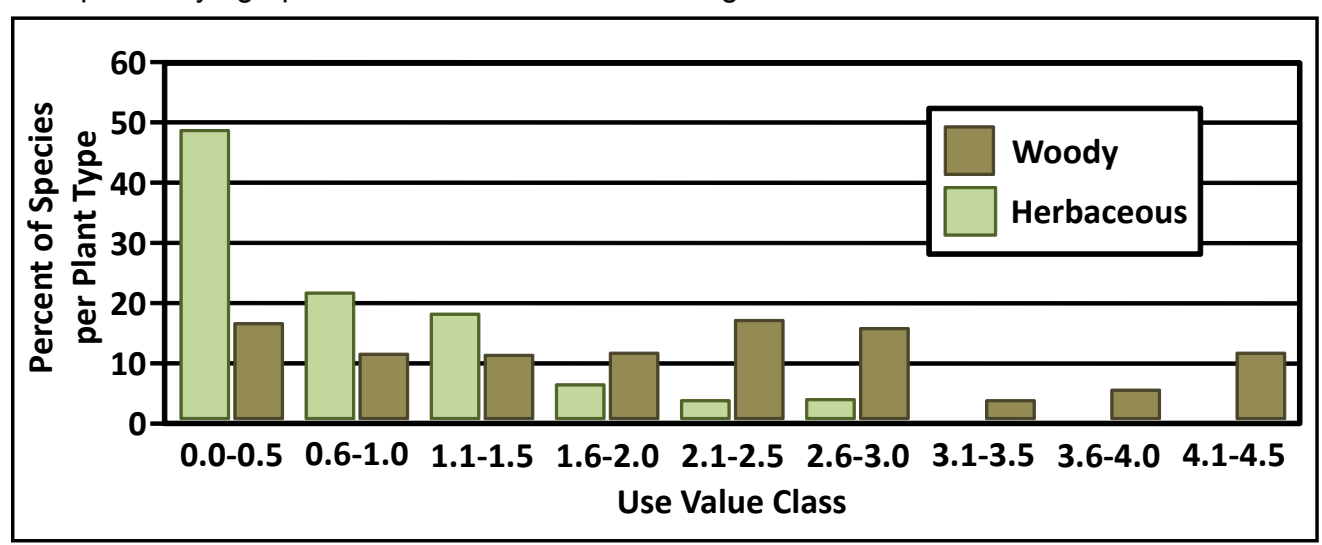

Figure 3. Percentage of species in each of the use value class for herbaceous and woody plant species reported by agropastoralists in South-western Niger. use-value classes were established with intervals of 0.5 (Figure 3 ) ranging from use values of 0.0 to 4.5 .

\section{Use of local plant species as traditional medicine}

The vast majority of herbaceous species (71 of 81) and all 36 woody species were identified as having medicinal value by the respondents (Figure 1). Details of the common medicinal herbaceous and woody species in the study site are presented in Table 2. Three woody species were known by nearly all the respondents namely Azadirachta indica A. Juss., Bauhinia rufescens Lam., and Prosopis africana (Guill. \& Perr.) Taub.. Most $(85 \%$ of the herbaceous and $67 \%$ of the woody) medicinal species in the study site are used to treat human ailments whereas only $11 \%$ of herbaceous and $19 \%$ the woody species had ethno-veterinary use according to the respondents. Four percent and $14 \%$ of the species are used to treat both human and animal ailments, according to the respondents. Leaves are the most frequently used plant part for treatment of human and or animal ailments (Figure 4) followed by a mixture of leaf and stem. The most common ailment that medicinal plants are used for was stomach problems (Figure 5). Both herbaceous ( $50 \%$ of the medicinal) and woody species $(90 \%)$, are used to treat stomach problem. It needs to be emphasized that stomach problem referred to by the respondents included many ailments such as stomach ache, abdominal pains, ulcer, digestive system disorders, and even female reproductive system disorders. Other major ailments reported by the respondents in our study that were treated by using local plant species included diarrhea, malaria, fresh wounds, skin diseases, rheumatism and sickle cell anaemia (Figure 5). The medicinal plants 


\section{Ayantunde et al. - Uses of Local Plant Species by Agropastoralists in South- western Niger}

Table 1. Use-value (means \pm standard error) by use categories * Mean values with no common superscript for each for herbaceous and woody plant species as determined by agropastoral communities in South-western Niger.

\begin{tabular}{|l|c|c|c|c|}
\hline \multirow{2}{*}{$\begin{array}{l}\text { Use } \\
\text { Category* }\end{array}$} & \multicolumn{4}{|c|}{ Use Value } \\
\cline { 2 - 5 } & \multicolumn{2}{|c|}{ Herbaceous } & \multicolumn{2}{c|}{ Woody } \\
\cline { 2 - 5 } & Mean & Species & Mean & Species \\
\hline Medicine & $0.75 \pm 0.08^{\mathrm{a}}$ & 71 & $2.01 \pm 0.21^{\mathrm{a}}$ & 36 \\
\hline Food & $0.95 \pm 0.11^{\mathrm{ab}}$ & 31 & $2.30 \pm 0.24^{\mathrm{a}}$ & 28 \\
\hline Forage & $0.73 \pm 0.07^{\mathrm{a}}$ & 73 & $2.11 \pm 0.21^{\mathrm{a}}$ & 34 \\
\hline Construction & $1.03 \pm 0.13^{\mathrm{b}}$ & 28 & $2.06 \pm 0.20^{\mathrm{a}}$ & 35 \\
\hline Firewood & $1.17 \pm 0.14^{\mathrm{b}}$ & 25 & $2.01 \pm 0.20^{\mathrm{a}}$ & 36 \\
\hline Other & $1.14 \pm 0.14^{\mathrm{b}}$ & 22 & $2.19 \pm 0.24^{\mathrm{a}}$ & 29 \\
\hline
\end{tabular}

use category within each plant type (herbaceous and woody plants) differ significantly $(P<0.05)$. There were significant differences between plant types (herbaceous versus woody plants) for all use categories $(P<0.05)$.

Table 2. Common medicinal species in the study site according to agropastoralist respondents $(n=205)$ in Southwestern Niger. Ordered from most to least commonly reported.

\begin{tabular}{|c|c|c|c|c|c|c|c|}
\hline Name & $\begin{array}{l}\text { No } \\
\operatorname{Re}^{1}\end{array}$ & $\begin{array}{l}\text { Use } \\
\text { Value }\end{array}$ & $\begin{array}{l}\text { Part } \\
\text { Used }\end{array}$ & $\begin{array}{l}\text { Man/ } \\
\text { Vet }^{2}\end{array}$ & Ailments Treated & Plant Habitat & $\begin{array}{l}\text { Species } \\
\text { Abundance }\end{array}$ \\
\hline \multicolumn{8}{|l|}{ Herbaceous species } \\
\hline Waltheria indica $\mathrm{L}$. & 132 & 1.32 & $\begin{array}{l}\text { Root, } \\
\text { Bark }\end{array}$ & Man & $\begin{array}{l}\text { Diarrhea, Wound, } \\
\text { Stomach ache }\end{array}$ & $\begin{array}{l}\text { Sand dunes, } \\
\text { sandy depression }\end{array}$ & $\begin{array}{l}\text { Moderately } \\
\text { available }\end{array}$ \\
\hline Momordica balsamina L. & 125 & 1.75 & $\begin{array}{l}\text { Leaf, } \\
\text { Stem }\end{array}$ & Man & Stomach ache & Sand dunes & Rare \\
\hline $\begin{array}{l}\text { Alysicarpus ovalifolius } \\
\text { (Schumach. \& Thonn.) } \\
\text { J. Léonard }\end{array}$ & 125 & 1.40 & $\begin{array}{l}\text { Leaf, } \\
\text { Stem }\end{array}$ & Man & $\begin{array}{l}\text { Malaria, } \\
\text { Stomach ache }\end{array}$ & Sand dunes & $\begin{array}{l}\text { Moderately } \\
\text { available }\end{array}$ \\
\hline $\begin{array}{l}\text { Striga hermonthica } \\
\text { (Delile) Benth. }\end{array}$ & 112 & 1.32 & $\begin{array}{l}\text { Leaf, } \\
\text { Stem }\end{array}$ & $\begin{array}{l}\text { Man, } \\
\text { Vet }\end{array}$ & $\begin{array}{l}\text { Wound, } \\
\text { Stomach ache }\end{array}$ & Sand dunes & $\begin{array}{l}\text { Moderately } \\
\text { available }\end{array}$ \\
\hline Tephrosia lupinifolia DC. & 100 & 1.02 & $\begin{array}{l}\text { Leaf, } \\
\text { Stem }\end{array}$ & Man & Stomach ache & Sand dunes & Rare \\
\hline \multicolumn{8}{|l|}{ Woody species } \\
\hline Azadirachta indica A. Juss. & 189 & 4.26 & $\begin{array}{l}\text { Leaf, } \\
\text { Bark, } \\
\text { Root }\end{array}$ & Man & $\begin{array}{l}\text { Stomach ache, } \\
\text { Malaria }\end{array}$ & $\begin{array}{l}\text { Sand dunes, } \\
\text { clay depression }\end{array}$ & $\begin{array}{l}\text { Moderately } \\
\text { available }\end{array}$ \\
\hline Bauhinia rufesens Lam. & 162 & 2.62 & $\begin{array}{l}\text { Leaf, } \\
\text { Root }\end{array}$ & Man & Stomach ache & $\begin{array}{l}\text { Sand dunes, } \\
\text { clay depression }\end{array}$ & Rare \\
\hline $\begin{array}{l}\text { Prosopis africana } \\
\text { (Guill. \& Perr.) Taub. }\end{array}$ & 157 & 3.94 & $\begin{array}{l}\text { Bark, } \\
\text { Leaf, } \\
\text { Root }\end{array}$ & Man & Stomach ache & Sand dunes & $\begin{array}{l}\text { Moderately } \\
\text { available }\end{array}$ \\
\hline Acacia albida Delile & 139 & 2.91 & $\begin{array}{l}\text { Bark, } \\
\text { Leaf }\end{array}$ & Man & Whitlow & $\begin{array}{l}\text { Clay depression, } \\
\text { sand dunes }\end{array}$ & $\begin{array}{l}\text { A bundant } \\
\text { (common) }\end{array}$ \\
\hline $\begin{array}{l}\text { Acacia nilotica (L.) } \\
\text { Willd. ex Delile }\end{array}$ & 121 & 3.10 & $\begin{array}{l}\text { Fruit, } \\
\text { Leaf }\end{array}$ & Man & $\begin{array}{l}\text { Rheumatism, } \\
\text { Sore throat }\end{array}$ & $\begin{array}{l}\text { sandy depression, } \\
\text { clay depression }\end{array}$ & $\begin{array}{l}\text { Moderately } \\
\text { available }\end{array}$ \\
\hline $\begin{array}{l}\text { Guiera senegalensis } \\
\text { J.F. Gmel. }\end{array}$ & 117 & 2.82 & Leaf & Man & Fresh wound & Sand dunes & Abundant \\
\hline Gardenia sokotensis Hutch. & 105 & 1.14 & $\begin{array}{l}\text { Leaf, } \\
\text { Stem }\end{array}$ & Man & Stomach ache & Plateau & $\begin{array}{l}\text { Moderately } \\
\text { available }\end{array}$ \\
\hline Ziziphus mauritiania Lam. & 101 & 2.83 & $\begin{array}{l}\text { Root, } \\
\text { Leaf }\end{array}$ & Man & $\begin{array}{l}\text { Whitlow, } \\
\text { Stomach ache }\end{array}$ & $\begin{array}{l}\text { Plateau, sand } \\
\text { dunes, loamy soil }\end{array}$ & $\begin{array}{l}\text { Moderately } \\
\text { available }\end{array}$ \\
\hline
\end{tabular}

${ }^{1} \mathrm{No} \operatorname{Re}=$ Number of respondents that recognized the medicinal value of the species.

${ }^{2} \mathrm{Man} / \mathrm{Vet}=$ Used for treating human and/or animal ailments. 


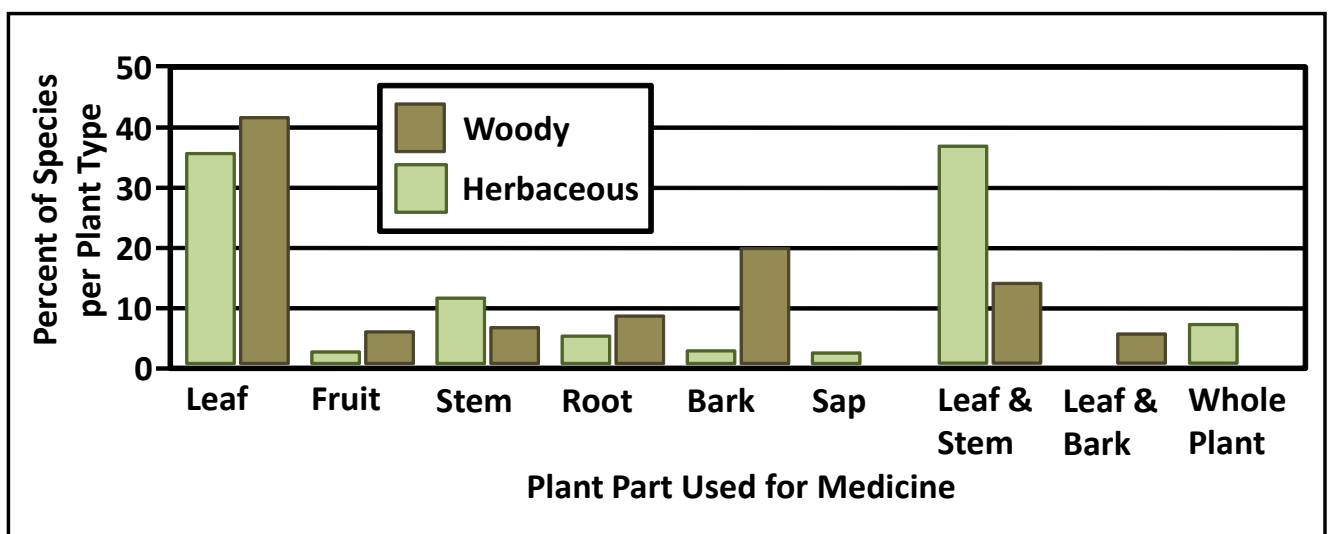

Figure 4. Parts of herbaceous $(n=71)$ and woody $(n=36)$ species used for medicine consumed by different animal species according to agropastoralists in South-western Niger.

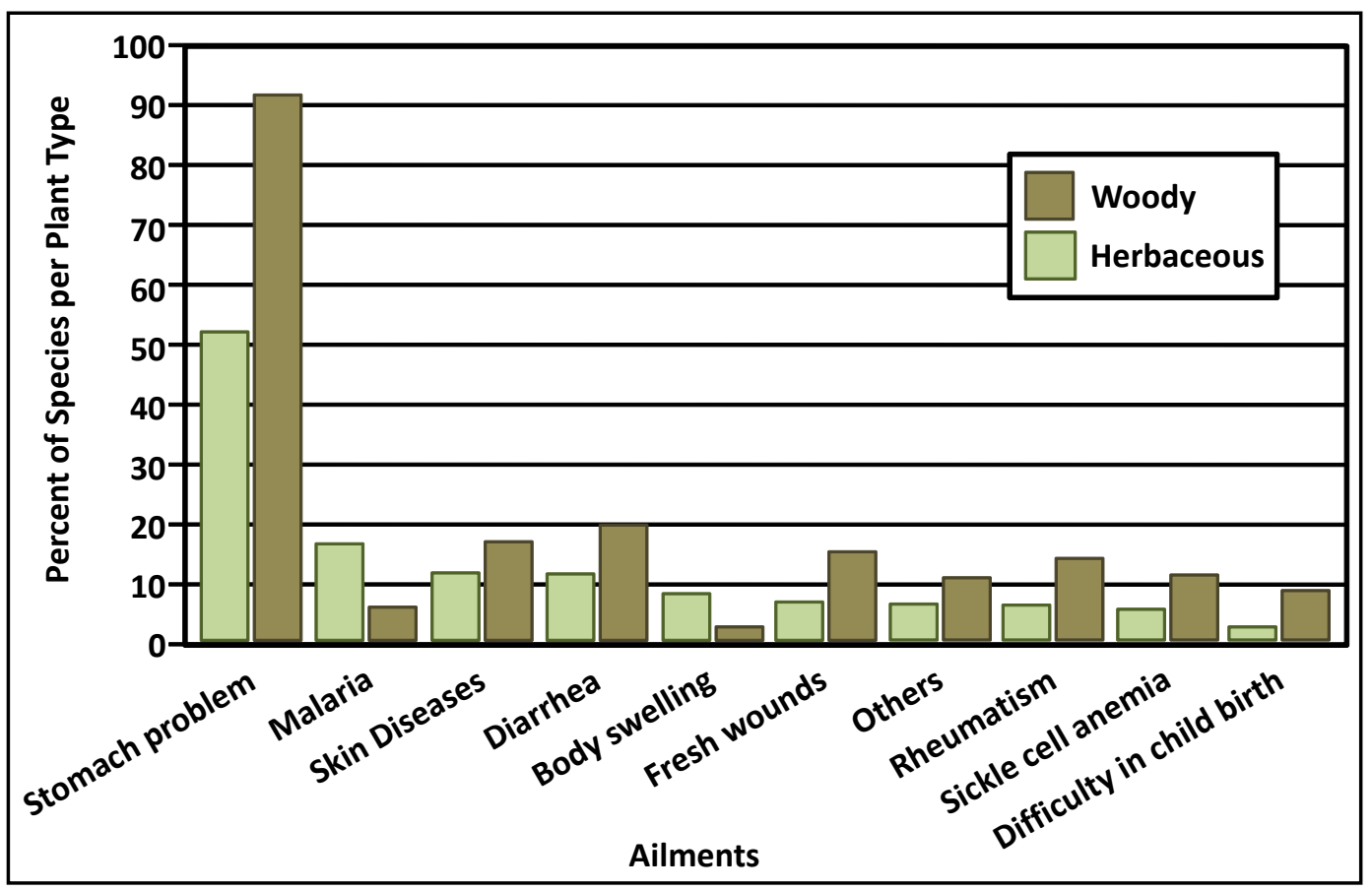

Figure 5. Major ailments that local herbaceous $(n=71)$ and woody $(n=36)$ species are used to treat according by agropastoralists in South-western Niger.

are usually prepared by elderly men and women by boiling, soaking in water, burning, roasting, sun drying and chewing, and often administered by them according to the respondents. In our study site, women are particularly charged with the responsibility for the well being of the children and other members of their households.

\section{Use of local plant species as food for human consumption}

Thirty-one of the useful 81 herbaceous species and 28 of the 36 woody species were reported as food for human consumption by the respondents (Figure 1). Four of the herbaceous food species were known by nearly all the respondents namely Ceratotheca sesamoides Endl., Cor- chorus tridens L., Citrullus colocynthis (L.) Schrad. and Leptadenia hastata Vatke. The leaves of the first two species serve in a common sauce for eating solid millet food, which is the most common daily meal in the region. The fruit of $C$. colocynthis is also widely used to prepare sauce while leaves of $L$. hastata are normally boiled and eaten as a vegetable with millet couscous and garri (a popular cassava food in West Africa). Leptadenia hastata is commonly eaten as a vegetable in the West African Sahel. The most common woody species consumed in the study site were Balanites aegyptiacus (L.) Delile, Piliostigma reticulatum (DC.) Hochst. and Annona senegalensis (Table 3 ). Leaves of $B$. eagypticum serve as sauce while its fruits are also commonly consumed. Both the leaves and fruits are sold in the local market. Other common food species 


\section{Ayantunde et al. - Uses of Local Plant Species by Agropastoralists in South- western Niger}

are listed in Table 3. Fruit is the common part of woody plants consumed in our study location whereas for herbaceous food species, leaves are the part being consumed (Figure 6). Most fruits of woody species are eaten raw while leaves are often boiled.

\section{Use of local plant species as forage}

Seventy-three of the useful 81 herbaceous species and 34 of the 36 woody species were reported as forage for animals by the respondents (Figure 1). There was quite a significant number of herbaceous and woody species that nearly all the respondents recognized for their nutritional value for the animals. The common herbaceous and woody forage species in the study location are presented in Table 4. According to the respondents, leaves and stems were

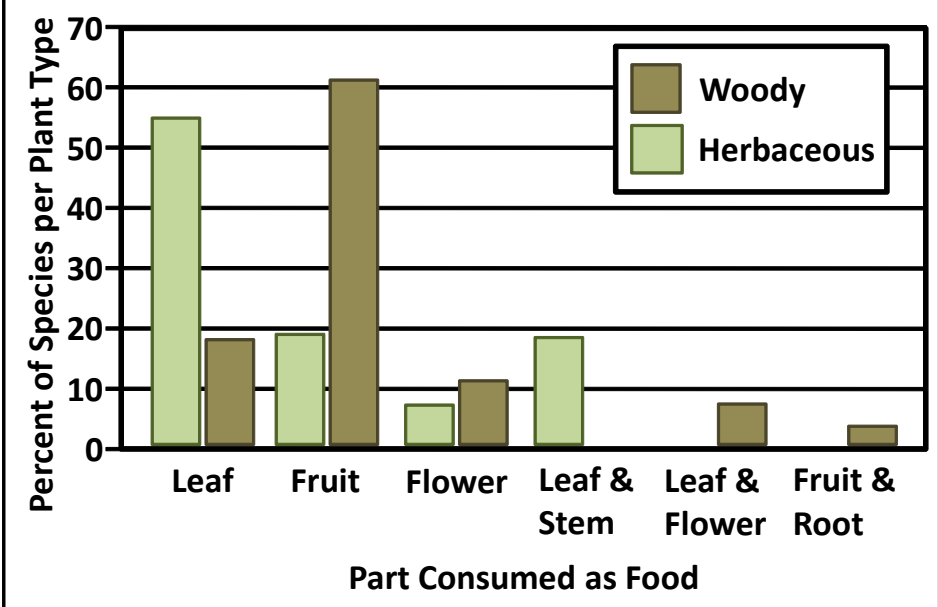

Figure 6. Herbaceous ( $n=31)$ and woody $(n=28)$ plant parts consumed as food by agropastoralists in South-western Niger. the parts of herbaceous plants preferred by the animals, while leaves and fruits were the woody plant parts most frequently eaten (Figure 7). The respondents reported that all above ground parts (leaf, stem, fruits) of 17 of the

73 herbaceous forage species are consumed by animals. These species were mainly annual grasses such as Eragrostis tremula Hochst. ex Steud., Ctenium elegans Kunth and Aristida sieberiana Trin. ex Spreng. Of the few dicot-

Table 3. Common food plant species in the study site according to the agropastoralist respondents $(n=205)$ in Southwestern Niger. Ordered from most to least commonly reported.

\begin{tabular}{|c|c|c|c|c|c|}
\hline Name & \begin{tabular}{l|} 
No \\
$\operatorname{Re}^{1}$ \\
\end{tabular} & $\begin{array}{l}\text { Use } \\
\text { Value }\end{array}$ & $\begin{array}{l}\text { Part } \\
\text { Used }\end{array}$ & Plant Habitat & Species Abundance \\
\hline \multicolumn{6}{|l|}{ Herbaceous species } \\
\hline Ceratotheca sesamoides Endl. & 195 & 2.32 & Leaf & Sandy depression, Sand dunes & Abundant \\
\hline Leptodenia hastata Vatke & 168 & 2.00 & Leaf & Sand dunes & Rare \\
\hline Corchorus tridens L. & 161 & 1.61 & Leaf & Sand dunes & Moderately available \\
\hline Citrullus colocynthis (L.) Schrad. & 154 & 1.69 & Fruit & Sand dunes, Clay depression & Moderately available \\
\hline Momordica balsamina L. & 117 & 1.75 & Fruit & Sand dunes & Rare \\
\hline \multicolumn{6}{|l|}{ Woody species } \\
\hline Balanites aegyptiacus (L.) Delile & 202 & 4.03 & $\begin{array}{l}\text { Leaf, } \\
\text { Fruit }\end{array}$ & Plateau, Sand dunes & Moderately available \\
\hline $\begin{array}{l}\text { Piliostigma reticulatum } \\
\text { (DC.) Hochst. }\end{array}$ & 199 & 4.40 & Fruit & $\begin{array}{l}\text { Clay depression, } \\
\text { Sandy loamy soil }\end{array}$ & Abundant \\
\hline Annona senegalensis Pers. & 188 & 2.98 & Fruit & Sandy depression, Sand dunes & Moderately available \\
\hline Hyphaene thebaica (L.) Mart. & 182 & 4.29 & $\begin{array}{l}\text { Root, } \\
\text { Fruit }\end{array}$ & Clay depression, Sand dunes & Rare \\
\hline $\begin{array}{l}\text { Sclerocarya birrea (A. Rich.) } \\
\text { Hochst. }\end{array}$ & 174 & 3.63 & $\begin{array}{l}\text { Leaf, } \\
\text { Fruit }\end{array}$ & Sand dunes, Sandy depression & Moderately available \\
\hline Ziziphus mauritiania Lam. & 163 & 2.83 & Fruit & Plateau, Sand dunes & Moderately available \\
\hline Parinari macrophylla Sabine & 147 & 2.23 & Fruit & Clay depression, Sand dunes & Moderately available \\
\hline Lannea microcarpa Engl. & 143 & 1.88 & Leaf & Plateau & Rare \\
\hline $\begin{array}{l}\text { Detarium microcarpum } \\
\text { Guill. \& Perr. }\end{array}$ & 134 & 2.41 & Fruit & Sand dunes, Sandy depression & Moderately available \\
\hline Adansonia digitata $\mathrm{L}$. & 126 & 1.68 & $\begin{array}{l}\text { Leaf, } \\
\text { Fruit }\end{array}$ & Clay depression & Rare \\
\hline
\end{tabular}

${ }^{1} \mathrm{No} \mathrm{Re}=$ number of respondents that recognized the value of the species as food for human consumption. 


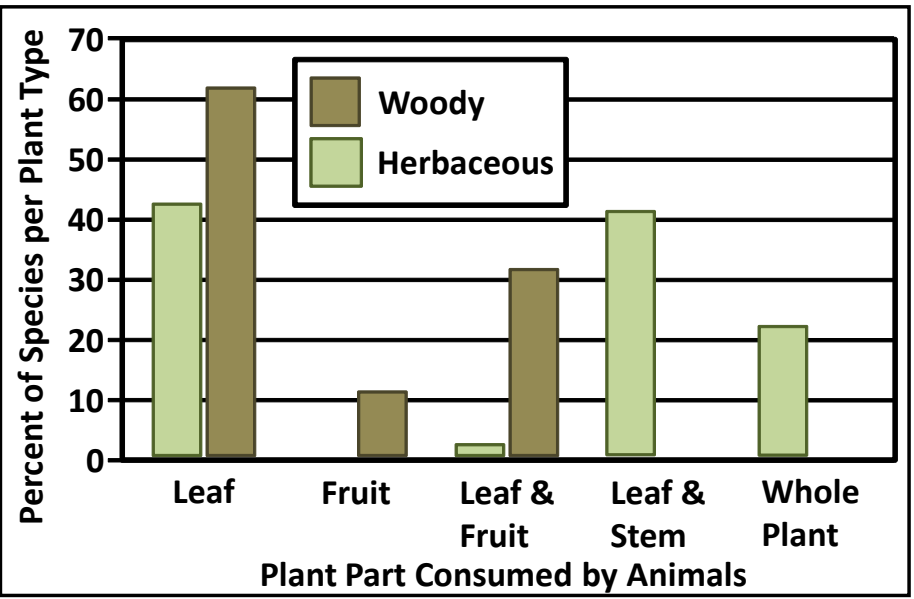

Figure 7. Parts of herbaceous $(n=73)$ and woody $(n=34)$ forage species consumed by the animals based on observations reported by agropastoralists in South-western Niger. yledonous species whose all the above ground parts are consumed by the animals, especially ruminants, are C. sesamoides, Zornia glochidiata, Rchb. ex DC. and A. ovalifolius.

The most common herbaceous forage species are reported in Table 4. The first three of these species are annual grasses that are preferred by cattle, sheep and goats. Cenchrus biflorus has prickly spikelets and is widespread in West African Sahel, especially on sandy soils (Maliki 1981). Ruminants like grazing it especially when it has just begun to sprout but it is normally avoided once the prickly spikelets mature. The animals return to graze it in the dry season after the spikelets have fallen. In several regions in the West African Sahel, $C$. biflorus hay constitutes the main available herbaceous fodder during the dry season. Cera-

Table 4. Common forage plant species in the study site according to the agropastoralist respondents $(n=205)$ in Southwestern Niger. Ordered from most to least commonly reported.

\begin{tabular}{|c|c|c|c|c|c|c|c|}
\hline Name & \begin{tabular}{|l|} 
No \\
$\operatorname{Re}^{1}$
\end{tabular} & $\begin{array}{l}\text { Use } \\
\text { Value }\end{array}$ & $\begin{array}{l}\text { Part } \\
\text { Used }\end{array}$ & $\mathrm{Pal}^{2}$ & Animal Species & Species Habitat & $\begin{array}{l}\text { Species } \\
\text { Abundance }\end{array}$ \\
\hline \multicolumn{8}{|l|}{ Herbaceous species } \\
\hline $\begin{array}{l}\text { Eragrostis tremula } \\
\text { Hochst. ex Steud. }\end{array}$ & 201 & 2.58 & $A \|^{3}$ & 4 & $\begin{array}{l}\text { Cattle, Sheep, } \\
\text { Goat, Donkey }\end{array}$ & Sand dunes & $\begin{array}{l}\text { Moderately } \\
\text { available }\end{array}$ \\
\hline $\begin{array}{l}\text { Cenchrus biflorus } \\
\text { Roxb. }\end{array}$ & 195 & 1.14 & $\begin{array}{l}\text { All } \\
\text { except } \\
\text { fruit }\end{array}$ & 3 & $\begin{array}{l}\text { Cattle, Sheep, Goat, } \\
\text { Horse, Donkey }\end{array}$ & Sand dunes & $\begin{array}{l}\text { Moderately } \\
\text { available }\end{array}$ \\
\hline $\begin{array}{l}\text { Ceratotheca } \\
\text { sesamoides Endl. }\end{array}$ & 192 & 2.32 & $A l^{3}$ & 3 & Cattle, Sheep, Goat & $\begin{array}{l}\text { Sand depression, } \\
\text { sand dunes }\end{array}$ & $\begin{array}{l}\text { Moderately } \\
\text { available }\end{array}$ \\
\hline Ctenium elegans Kunth & 190 & 2.57 & $A \|^{3}$ & 3 & $\begin{array}{l}\text { Cattle, Sheep, Goat, } \\
\text { Horse, Donkey }\end{array}$ & $\begin{array}{l}\text { Sand dunes, } \\
\text { plateau }\end{array}$ & $\begin{array}{l}\text { Moderately } \\
\text { available }\end{array}$ \\
\hline $\begin{array}{l}\text { Citrullus colocynthis } \\
\text { (L.) Schrad. }\end{array}$ & 174 & 1.69 & $\begin{array}{l}\text { Leaf, } \\
\text { Fruit }\end{array}$ & 3 & $\begin{array}{l}\text { Cattle, Sheep, Goat, } \\
\text { Horse, Donkey, Camel }\end{array}$ & $\begin{array}{l}\text { Sand depression, } \\
\text { sand dunes }\end{array}$ & $\begin{array}{l}\text { Moderately } \\
\text { available }\end{array}$ \\
\hline $\begin{array}{l}\text { Aristida sieberiana Trin. } \\
\text { ex Spreng. }\end{array}$ & 173 & 2.19 & $A \|^{3}$ & 2 & $\begin{array}{l}\text { Cattle, Sheep, } \\
\text { Goat, Donkey }\end{array}$ & $\begin{array}{l}\text { Sand dunes, } \\
\text { sandy depression }\end{array}$ & $\begin{array}{l}\text { Moderately } \\
\text { available }\end{array}$ \\
\hline $\begin{array}{l}\text { Mitracarpus hirtus } \\
\text { (L.) DC. }\end{array}$ & 172 & 1.21 & $A \|^{3}$ & 2 & Cattle, Sheep, Goat & Sand dunes & $\begin{array}{l}\text { Moderately } \\
\text { available }\end{array}$ \\
\hline $\begin{array}{l}\text { Leptadenia hastata } \\
\text { Vatke }\end{array}$ & 167 & 2.00 & $\begin{array}{l}\text { Leaf, } \\
\text { Stem }\end{array}$ & 2 & $\begin{array}{l}\text { Cattle, Sheep, } \\
\text { Goat, Donkey }\end{array}$ & Sand dunes & Rare \\
\hline Corchorus tridens L. & 162 & 1.61 & $\begin{array}{l}\text { Leaf, } \\
\text { Stem }\end{array}$ & 3 & Cattle, Sheep, Goat & $\begin{array}{l}\text { Sand dunes, } \\
\text { clay depression }\end{array}$ & Rare \\
\hline \multicolumn{8}{|l|}{ Woody species } \\
\hline $\begin{array}{l}\text { Piliostigma reticulatum } \\
\text { (DC.) Hochst. }\end{array}$ & 204 & 4.40 & $\begin{array}{l}\text { Leaf, } \\
\text { Fruit }\end{array}$ & 2 & $\begin{array}{l}\text { Cattle, Sheep, } \\
\text { Goat, Camel }\end{array}$ & Clay depression & Common \\
\hline $\begin{array}{l}\text { Balanites aegyptiacus } \\
\text { (L.) Delile }\end{array}$ & 204 & 4.03 & $\begin{array}{l}\text { Leaf, } \\
\text { Flower, } \\
\text { Fruit }\end{array}$ & 3 & Camel, Sheep, Goat & $\begin{array}{l}\text { Plateau, sand } \\
\text { dunes }\end{array}$ & Rare \\
\hline Acacia albida Delile & 196 & 2.91 & $\begin{array}{l}\text { Leaf, } \\
\text { Fruit }\end{array}$ & 3 & $\begin{array}{l}\text { Cattle, Sheep, } \\
\text { Goat, Camel }\end{array}$ & $\begin{array}{l}\text { Clay depression, } \\
\text { sand dunes }\end{array}$ & Common \\
\hline
\end{tabular}




\section{Ayantunde et al. - Uses of Local Plant Species by Agropastoralists in South- western Niger}

Table 4(cont). Common forage plant species in the study site according to the agropastoralist respondents $(n=205)$ in South-western Niger.

\begin{tabular}{|l|c|c|l|c|l|l|l|}
\hline Name & $\begin{array}{l}\text { No } \\
\mathbf{R e}^{1}\end{array}$ & $\begin{array}{l}\text { Use } \\
\text { Value }\end{array}$ & $\begin{array}{l}\text { Part } \\
\text { Used }\end{array}$ & $\mathbf{P a l}^{2}$ & Animal Species & Species Habitat & $\begin{array}{l}\text { Species } \\
\text { Abundance }\end{array}$ \\
\hline $\begin{array}{l}\text { Hyphaene thebaica } \\
\text { (L.) Mart. }\end{array}$ & 195 & 4.29 & Leaf & 2 & Cattle, Sheep, Goat & $\begin{array}{l}\text { Sand dunes, } \\
\text { clay depression }\end{array}$ & Rare \\
\hline $\begin{array}{l}\text { Sclerocarya birrea } \\
\text { (A. Rich.) Hochst. }\end{array}$ & 182 & 3.63 & $\begin{array}{l}\text { Leaf, } \\
\text { Fruit }\end{array}$ & 2 & $\begin{array}{l}\text { Cattle, Sheep, } \\
\text { Goat, Camel }\end{array}$ & $\begin{array}{l}\text { Sand dunes, } \\
\text { sandy depression }\end{array}$ & $\begin{array}{l}\text { Moderately } \\
\text { available }\end{array}$ \\
\hline $\begin{array}{l}\text { Prosopis africana } \\
\text { (Guill. \& Perr.) Taub. }\end{array}$ & 179 & 3.94 & Leaf & 2 & $\begin{array}{l}\text { Cattle, Sheep, Goat, } \\
\text { Donkey, Camel, Horse }\end{array}$ & Sand dunes & $\begin{array}{l}\text { Moderately } \\
\text { available }\end{array}$ \\
\hline $\begin{array}{l}\text { Azadirachta indica } \\
\text { A. Juss. }\end{array}$ & 175 & 4.29 & Leaf & 2 & Camel, Goat, Sheep & Sand dunes & $\begin{array}{l}\text { Moderately } \\
\text { available }\end{array}$ \\
\hline
\end{tabular}

${ }^{1} \mathrm{No} \mathrm{Re}=$ number of respondents that recognized the value of the species as forage for animals.

${ }^{2} \mathrm{Pal}=$ Palatability of the species: 1 = Refused by animal; 2 = Only eaten if there is nothing else to eat; $3=$ Generally eaten; $4=$ Highly preferred.

${ }^{3}$ All $=$ All above ground parts used.

totheca sesamoides is an annual dicotyledonous plant that is highly sought by man and animal.

Of the 87 herbaceous species used for the interview, only $6 \%$ was highly preferred (very palatable) by ruminants (Figure 8). These species were E. tremula, C. sesamoides, Z. glochidiata, A. ovalifolius and Pandiaka involucrata (Moq.) Hook.f. None of the 36 woody species were highly preferred by the ruminants. Nine herbaceous species and two woody species found in the study location are completely rejected by ruminants. Herbaceous species rejected by the animals included Acanthospermum hispidum DC., Rogeria adenophylla J. Gay ex Delile, Sporobolus microprotus Stapf and Pergularia tomentosa while the two woody species rejected by the ruminants were Cassia sieberiana and Vitellaria paradoxa C.F. Gaertn. Rogeria adenophylla and $P$. tomentosa are rejected because of their toxicity. Acanthospermum hispidium is rejected due to its offensive odor. It is not clear why S. micropro-

tus, V. paradoxa and C. sieberiana are rejected by the ruminants. In the latter case, a possible reason could be the rarity of the tree in the study location. The few plants (less than 10 in number) found in the study area are very tall and inaccessible to ruminants. Cassia sieberiana DC. is rejected by ruminants due to its offensive odor. Most of the herbaceous species rejected by ruminants are dicotyledonous plants.

Common woody plants used as fodder in South-western Niger are listed in Table 4. Leaves and young fruits of $P$. reticulatum are consumed by cattle, sheep, goats and camels. Balanites aegyptiacus is one of the most commonly found trees in the Sahel. It is quite resistant to lack of humidity and drought. Its leaves and fruits are very much sought after by camels and small ruminants (Maliki 1981). The leaves and fruits of $A$. albida are also particularly sought after by small ruminants and camels. Nearly $95 \%$ of the herbaceous $(n=73)$ and woody $(n=34)$ for-
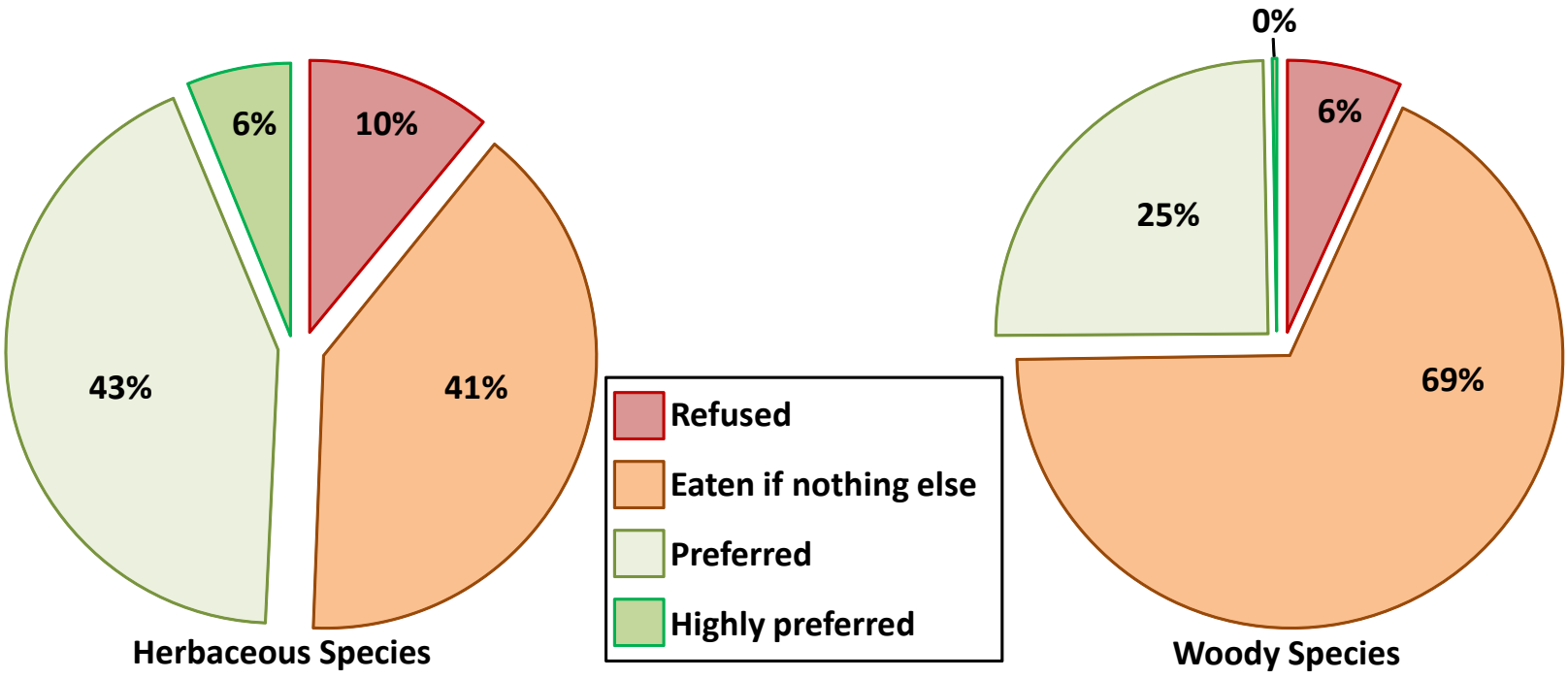

Figure 8. Palatability of herbaceous $(n=87)$ and woody $(n=36)$ species by ruminants according to observations reported by agropastoralists in South-western Niger. 
age species were consumed by the ruminants (cattle, sheep and goats) according to the respondents (Figure 9). Camels were said to prefer tree leaves and fruits. According to the respondents, donkeys and horses consumed relatively few herbaceous (donkey: 19; horse: 15) and woody (donkey: 4; horse: 3 ) species compared to the ruminants.

\section{Use of local plant species for household construction and firewood}

Household construction implies building of a household hut or settlement, roofing and fencing. Only 28 of the 81 useful herbaceous species are used for construction whereas all the 36 woody species used for the interview were reported to be useful for construction (Figure 1). Common herbaceous and woody species used for household construction are listed in Table 5. All of the common herbaceous species are grasses and are used mainly for building huts. The woody species are used as poles for the huts, and as roofing materials for mud houses. They are also used to make doors for the hut or mud house and for fencing. Build-

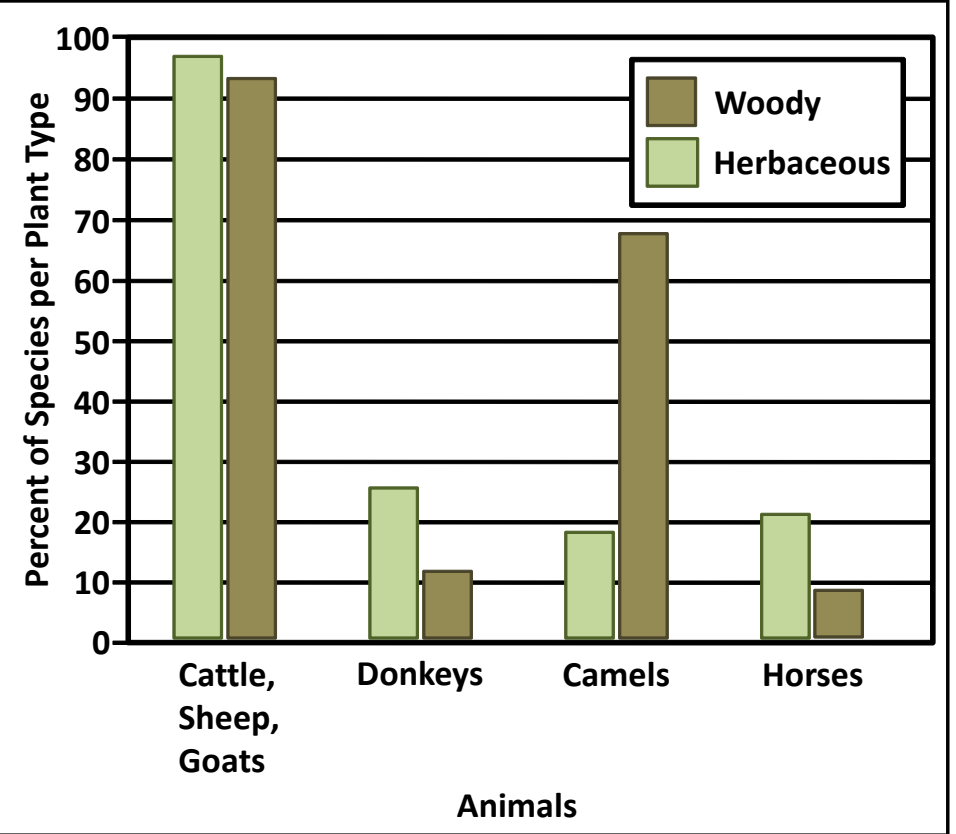

Figure 9. Herbaceous $(n=73)$ and woody $(n=34)$ forage species consumed by different animals according to agropastoralists in Southwestern Niger. ing of a new hut or mud house and repair is mainly the building or repairing the hut or mud house. In addition, task of young men and adults in the study site. However, fetching of water needed for the building of mud house it is women's role to prepare food for the men who are is largely women's tasks. The main parts of the herba-

Table 5. Common plant species used for household construction in the study sites according to the agropastoralist respondents $(n=205)$ in South-western Niger.

\begin{tabular}{|c|c|c|c|c|c|}
\hline Name & $\begin{array}{l}\text { No } \\
\operatorname{Re}^{1}\end{array}$ & $\begin{array}{l}\text { Use } \\
\text { Value }\end{array}$ & $\begin{array}{l}\text { Part } \\
\text { Used }\end{array}$ & Species Habitat & Species Abundance \\
\hline \multicolumn{6}{|l|}{ Herbaceous species } \\
\hline Ctenium elegans Kunth & 186 & 2.57 & Stem & Sand dunes, Plateau & Moderately available \\
\hline Eragrostis tremula Hochst. ex Steud. & 144 & 2.58 & Stem & Sand dunes & Moderately available \\
\hline Aristida sieberiana Trin. ex Spreng. & 142 & 2.19 & Stem & $\begin{array}{l}\text { Sand dunes, Sandy } \\
\text { depression }\end{array}$ & Moderately available \\
\hline Andropogon gayanus Kunth & 135 & 1.95 & Stem & $\begin{array}{l}\text { Sand dunes, Sandy } \\
\text { depression }\end{array}$ & Moderately available \\
\hline \multicolumn{6}{|l|}{ Woody species } \\
\hline Azardirachta indica A. Juss. & 194 & 4.26 & Stem & Sand dunes & Moderately available \\
\hline Piliostigma reticulatum (DC.) Hochst. & 192 & 4.40 & $\begin{array}{l}\text { Bark, } \\
\text { Stem }\end{array}$ & Clay depression & Very common \\
\hline Hyphaene thebaica (L.) Mart. & 191 & 4.29 & Leaf & $\begin{array}{l}\text { Sand dunes, Clay } \\
\text { depression }\end{array}$ & Rare \\
\hline Prosopis africana (Guill. \& Perr.) Taub. & 177 & 3.94 & Stem & Sand dunes & Moderately available \\
\hline Guiera senegalensis J.F. Gmel. & 153 & 2.82 & Stem & Sand dunes & Very common \\
\hline Combretum micranthum G. Don & 130 & 2.07 & Stem & Plateau & Moderately available \\
\hline Acacia nilotica (L.) Willd. ex Delile & 107 & 3.10 & Stem & $\begin{array}{l}\text { Sand dunes, Sandy } \\
\text { depression }\end{array}$ & Moderately available \\
\hline Combretum glutinosum Perr. & 105 & 2.28 & Stem & Sand dunes & Moderately available \\
\hline
\end{tabular}

${ }^{1} \mathrm{No} \mathrm{Re}=$ number of respondents that recognized the usefulness of the species for household construction. 


\section{Ayantunde et al. - Uses of Local Plant Species by Agropastoralists in South- western Niger}

ceous plants used for construction are the aboveground parts (leaves and stems) while stem (trunk) of the woody species is the main part being used for household settlements. Expectedly, few herbaceous species are used as firewood whereas all the woody species are used for household cooking (Figure 1). Herbaceous species used for cooking are mainly used to start or revive the fire for cooking. Common woody species used as firewood are listed in Table 6. Quite often the woody plants near to the village are the most exploited as firewood. In the study location, women normally collect deadwood for cooking but may also prune live branches or cut shrubs if deadwood is not available. Not only the rural populations rely on woody species as firewood, many urban households in West African Sahel also rely on purchased firewood.

\section{Other uses of local plant species}

Other uses of herbaceous and woody plant species in the study location included fabrication of farm tools, traditional furniture and musical instruments, making of household utensils, ornaments and decorations, ritual uses and burial (Figure 10). Only woody species are used for fabrication of farm tools such as handles for hoe, digger and cutlass. According to the respondents, common woody species used for farm tools were $S$. birrea, C. glutinosum, $D$. microcarpum and $C$. nigricans. For household utensils such as wooden spoons, mortar and pestles, the common woody species used were $S$. birrea, $P$. africana, and Calotropis procera (Aiton) W.T. Aiton while herbaceous species were used to make brooms, namely E. tremula, $C$. elegans and $A$. sieberiana. Common woody species used for traditional furniture such as beds, chairs and tables were C. micranthum, $C$. procera and B. rufesens. Common herbaceous species used for traditional furniture such as mats included Chrozophora senegalensis (Lam.) A. Juss. ex Spreng. and C. elegans. For dyeing and decoration, the bark of $P$. reticulatum is commonly used according to the respondents. The bark is normally soaked in water and the extract is used for dyeing and as cosmetics. The bark of $B$. aegyptiacus is used as soap for washing clothes and household utensils. For human burial, the small branches of $C$. glutinosum are used for making coffins in the study site. For ritual uses, 8 herbaceous species were mentioned which included $E$. tremula, Polycarpaea eriantha Hochst. ex A. Rich., M. hirtus, and $C$. sesamoides. Information on ritual uses of these species was not given by the respondents. This is expected given the reluctance of traditional healers and herbalists to release information on their activities and many taboos that are associated with spiritism and exorcism.

\section{Discussion}

The agropastoralists interviewed in this study were highly aware of the usefulness of nearly all the woody plant species. Awareness of the actual and/or potential use of the herbaceous species varied markedly among the six use categories with a strong bias towards the utilization as animal fodder and for traditional medicine. The significantly higher use-values for the woody plant species compared to the herbaceous species support the 'apparency' hypothesis that plants that are visible and dominant in the ecosystems are more likely to be used than those that are non-apparent which are mainly herbaceous species with short life cycles. These results agree with the past ethnobotanical studies in the West African Sahel (Diop et al. 2005, Lykke et al. 2004, Nikiema 2005) which reported the multipurpose uses of woody plant species. High-use value for a plant species may be an indication of high usepressure and this may call for specific conservation measures to prevent over-exploitation of the species. Given the widespread report of the multipurpose uses of tree

Table 6. Common plant species used for firewood in the study sites according to the agropastoralist respondents $(\mathrm{n}=$ 205) in South-western Niger.

\begin{tabular}{|l|l|l|l|l|l|l|}
\hline Name & $\begin{array}{l}\text { No } \\
\mathbf{R e}^{1}\end{array}$ & $\begin{array}{l}\text { Use } \\
\text { Value }\end{array}$ & $\begin{array}{l}\text { Part } \\
\text { Used }\end{array}$ & Species Habitat & Species abundance \\
\hline Woody species & 200 & 4.40 & Stem & Clay depression & Very common \\
\hline Piliostigma reticulatum (DC.) Hochst. & 197 & 4.26 & Stem & Sand dunes & Moderately available \\
\hline Azadirachta indica A. Juss. & 187 & 2.91 & Stem & Valley, Sand dunes & Very common \\
\hline Acacia albida Delile & 186 & 4.03 & Stem & Plateau, Sand dunes & Moderately available \\
\hline Balanites aegyptiacus (L.) Delile & 175 & 3.94 & Stem & Sand dunes & Moderately available \\
\hline Prosopis africana (Guill.\& Perr.) Taub. & 161 & 3.63 & Stem & Sand dunes, Valley & Moderately available \\
\hline Sclerocarya birrea (A. Rich.) Hochst. & 157 & 3.10 & Stem & Sand dunes, Valley & Moderately available \\
\hline Acacia nilotica (L.) Willd. ex Delile & 153 & 2.82 & Stem & Sand dunes & Very common \\
\hline Guiera senegalensis J.F. Gmel. & 140 & 4.29 & Stem & Sand dunes, Valley & Rare \\
\hline Hyphaene thebaica (L.) Mart. & 139 & 2.28 & Stem & Sand dunes & Moderately available \\
\hline Combretum glutinosum Perr. &
\end{tabular}

${ }^{1} \mathrm{No} \mathrm{Re}=$ number of respondents that recognized the usefulness of the species as firewood. 


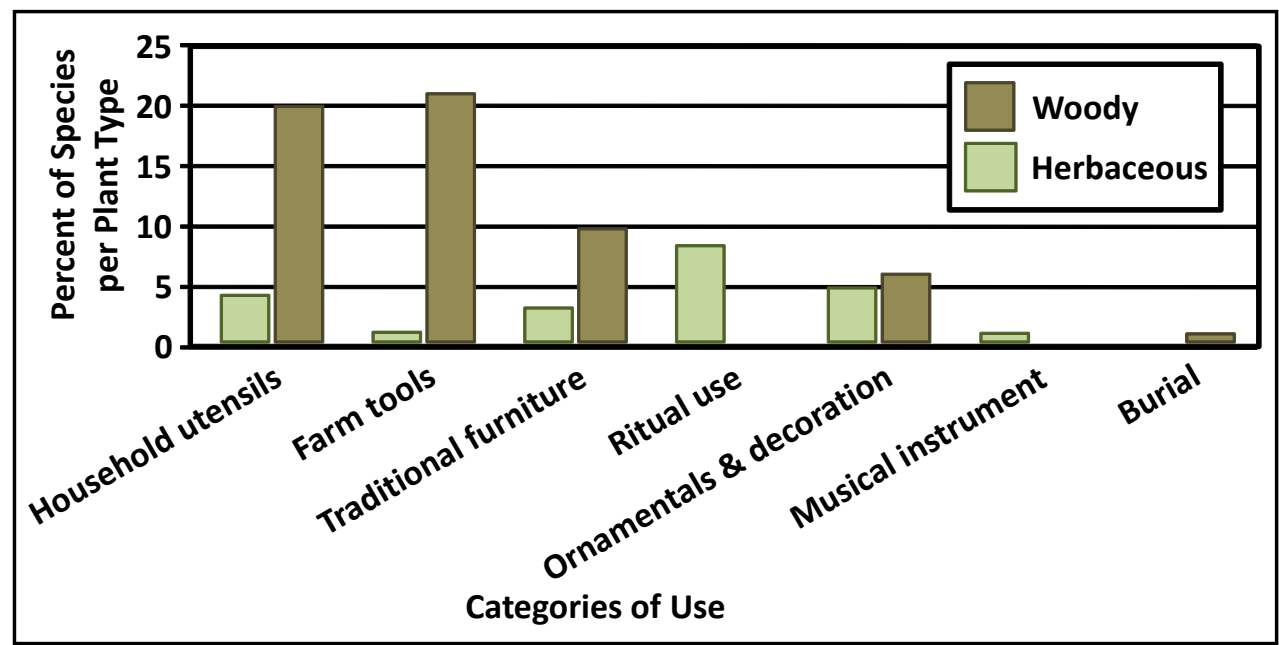

Figure 10. Other uses of herbaceous and woody species in the study site as reported by agropastoralists in South-western Niger.

species in the study site, conservation measures addressing woody plants may stand a better chance of succeeding than measures that only seek to protect species that are not commonly used by the communities. However, caution should be exercised in interpreting the use-values results as there was no clear distinction between the actual use and potential use by the informants (Albuquerque \& Lucena 2005).

The widespread use of leaves for traditional medicine in our study is in accordance with the findings of Ricker (2002) in northern Nigeria, where leaves are the most widely plant part used for traditional medicine. The widespread use of local plants to treat stomach related problems in our study agrees with the observation made by Maundu et al. (2001) in their study on ethnobotany of Loita Massai in Kenya that gastro-intestinal problems is the leading ailment for which local plants are used. The uses of local plants for traditional medicine are often site specific and influenced by cultural and religious beliefs of the people. In our study site, it is common to find people, especially Muslim traditional healers called marabouts using traditional medicine together with quotations from the Koran due to the dominance of Islam in the region. Sometimes, the marabouts use divination to ascertain the root cause of the sickness. The large number of plants used for traditional medicine in our study site illustrates the important role played by local plant species in the health of the rural communities. The majority of rural communities will continue to rely on traditional medicine in the future for much of their primary health care due to poverty and the high cost of western-style medical care (Lykke et al. 2004). The majority of the population in our study site relies on traditional medical practitioners and only consults western medical practitioners as a last resort.

The low number of herbaceous species reported as useful for human consumption could be partly attributed to the seasonal availability of most herbaceous species in the study site. Another factor may be that many herbaceous species are consumed mainly when there is crop failure and famine, e.g., grains of $C$. biflorus and leaves of Senna obtusifolia (L.) H.S. Irwin \& Barneby and Cassia occidentalis L. Relatively few plant species are used for human consumption in the study site confirming the widely held view that man consumes only few species of the available plant resources (Kiambi \& Attah-Krah 2003).

The high percentage of herbaceous plants recognized as useful forage in the study area is a consequence of low species diversity which often characterizes most Sahelian rangelands. However, the relative importance of herbaceous species as forage in the study area is a reflection of the importance of livestock in the economy of the agropastoral communities. The common practice of harvesting dry herbaceous plants (bush hay) in the study site to fatten sheep or to sell provides opportunity to learn about forage species and this might have enhanced the local knowledge. Tree fodder is particularly important as animal feed in the late dry season (April - June) in the West African Sahel when there are virtually no herbaceous species left for grazing and crop residues are scarce. However, tree fodder is a good nitrogen supplement to poor quality residues (Thorne et al. 1999). The major limitation to their utilization by ruminants is high tannin content (Morrison et al. 1996).

The response of the interviewees as regards the dominance of tree leaves and fruits in camel's diets agrees with the report of Kaufmann (1998) on pastoral camel husbandry in northern Kenya. It is quite interesting that the response of the interviewees showed a similar number of herbaceous and woody species consumed by donkeys and horses in view of their similar digestive system. Both are monogastric herbivores, thus they eat roughages and utilize cellulose and hemicellulose efficiently. They graze 


\section{Ayantunde et al. - Uses of Local Plant Species by Agropastoralists in South- western Niger}

on bushes, scrub vegetation and bark, as well as on grass (Aganga \& Tsopito 1998). In spite of their similar digestive systems, donkeys need more fiber and less protein in their diets than horses. Another major difference in feeding behavior of donkeys compared to horses is coprophagy (eating of their own feces). This is common among young donkeys, which often eat the feces of their dams within a few months of birth (Aganga \& Tsopito 1998). This is viewed as a way for the young donkeys to obtain cellulose digesting bacteria and other microbes, which are abundant in the feces. Adult, well-fed donkeys on a balanced diet do not normally practice coprophagy.

Ethnobotanical study provides a means to create awareness of the conservation needs of the local species. Through our survey, we observed that the informants admitted the serious threat some of the valuable woody species face if they continue to exploit them without putting in place regeneration practices. Given the site-specificity of traditional uses of plant species, every ethnobotanical study is therefore a contribution to understanding and documentation of the indigenous ecological knowledge. To go beyond documentation of local knowledge of plant species and facilitate community-based conservation measures, it is important to share the main results from the ethnobotany survey with the community and encourage the people to identify community actions that can address main issues from the survey and the possible contributions by the development agencies. Since the local communities are dependent on the resources for their livelihood, they are in better positions to assess the true costs and benefits of any conservation measures coming from outside. Cultural diversity is closely linked to biodiversity; conserving biodiversity can therefore help to strengthen cultural integrity and values of rural communities.

\section{Conclusion}

In conclusion, this study has shown the relative importance of herbaceous and woody plant species in South-western Niger and the tendency to exploit more visible and dominant species, especially woody plants by the agropastoral communities. Major uses of local plant species are for traditional medicine, human consumption, animal feed, household construction and firewood. The results of this study demonstrate the necessity of proper documentation of indigenous ecological knowledge in order to preserve the wisdom and practices of past generations for present benefit and for future local and global use. Results from this study confirm that availability of a plant largely determines its utilization. Given the low diversity of the Sahelian flora in comparison to other arid or semi-arid zones such as Karoo-Namib in Southern Africa and the horn of Africa (Hiernaux \& Ayantunde 2004) caution should be exercised in extrapolating the results of our study. The question of whether the availability of plant species is a reflection of the strength of anthropogenic factors which favor them is not considered in this study. Results from this study also show the necessity for targeted community-based conservation measures to protect species with high use-pressure as suggested by use-value technique.

\section{Acknowledgements}

We thank Adamou Kalilou, Issa Karimou, Oumarou Moumini and Seybou Garba of ILRI Niamey, Niger for their outstanding assistance in the conduct of enthnobotany survey. This study was part of the project "Desert Margins Program (DMP)" partly funded by Global Environment Facility (GEF), with the overall goal of arresting land degradation and conservation of biodiversity in desert margins of sub-Saharan Africa. We also acknowledge the valuable comments of the two reviewers about how to improve the content of the manuscript.

\section{Literature Cited}

Aganga, A.A.\& C.M. Tsopito. 1998. A note on the feeding behaviour of domestic donkeys: a Botswana case study. Applied Animal Behaviour Science 60: 235-239.

Albuquerque, U.P. \& R.F.P. Lucena. 2005. Can apparency affect the use of plants by local people in tropical forests? Interciencia 30:506-511.

Albuquerque, U.P., L.H.C. Andrade \& A.C.O. Silva. 2005. Use of plant resources in a seasonal dry forest (Northeastern Brazil). Acta Botanica Brasilica 19: 27-38.

Ayantunde, A.A., M. Briejer, P. Hiernaux, H.M.J. Udo \& R. Tabo. 2008. Botanical knowledge and its differentiation by age, gender and ethnicity in South-western Niger. Human Ecology 36:881-889.

Diop, M., B. Kaya, A. Niang \& A. Olivier. 2005. Les Espèces Ligneuses et Leurs Usages: Les preferences des paysans dans le Cercle de Ségou, au Mali. ICRAF working paper no. 9. World Agroforestry Centre Nairobi, Kenya.

Hamilton, A.C., P. Shengji, J. Kessy, A.A. Khan, S. LagosWitte \& Z.K. Shinwari. 2003. The Purposes and Teaching of Applied Ethnobotany. People and Plants working paper no. 11. Surrey, U.K.

Hiernaux, P. \& A.A. Ayantunde. 2004. The Fakara: A semiarid agro-ecosystems under stress. Report of research activities of International Livestock Research Institute (ILRI) in Fakara, South-western Niger, between 1994 and 2002. Submitted to Desert Margins Program, ICRISAT Niamey, Niger.

Hoffman, B. \& T. Gallaher. 2007. Important indices in ethnobotany. Ethnobotany Research \& Applications 5:201218. 
Hutchinson, J. \& J.M. Dalziel. 1954-1972. Flora of West Tropical Africa. 2nd edition, Volume 1-3. Edited by R.W.J. Keay \& F.N. Hepper. Crown Agents for Overseas Government and Administration, London, UK.

Kaufmann, B. 1998. Analysis of Pastoral Camel Husbandry in Northern Kenya. Hohenheim Tropical Agricultural series 5. Margraf, Weikersheim, Germany.

Kiambi, D. \& K. Atta-Krah. 2003. Plant genetic resources in the global and African setting. Pp. 33-52 in Plant Resources in Tropical Africa. Proceedings of the first PROTA International workshop, 23-25 September 2002, Nairobi, Kenya. Edited by G.H. Schmelzer \& E.A. Omino. PROTA Foundation, Wageningen, the Netherlands.

Kiringe, J.W. 2006. A survey of traditional health remedies used by the Maasai of southern Kaijiado district, Kenya. Ethnobotany Research \& Applications 4:61-73.

Ladio, A., M. Lozada \& M. Weigandt. 2007. Comparison of traditional wild plant knowledge between aboriginal communities inhabiting arid and forest environments in $\mathrm{Pa}$ tagonia, Argentina. Journal of Arid Environments 69:695715.

Lebel, T., J.D. Taupin \& N. D'Amato. 1997. Rainfall monitoring during Hapex-Sahel. 1. General rainfall conditions and climatology. Journal of Hydrology 188:74-96.

Lucena, R.F.P., V.T. Nascimento, E.M. Araujo \& U.P. Albuquerque. 2008. Local uses of native plants in an area of Caatinga vegetation (Pernambuco, NE Brazil). Ethnobotany Research \& Applications 6:3-13.

Lykke, A.M., M.K. Kristensen \& Ganaba S. 2004. Valuation of local use and dynamics of 56 woody species in the Sahel. Biodiversity and Conservation 13:1961-1990.

Maliki, A.B. 1981. Ngaynaaka: l'Elevage selon les WoDaaBe du Niger. Rapport préliminaire: Project gestion des pâturages, Ministère du Dévelopmement Rural, Tahua, Niger.

Maundu, P., D.J. Berger, C. ole Saitabau, J. Nasieku, M. Kipelian, S.G. Mathenge, Y. Morimoto \& R. Höft. 2001. Ethnobotany of the Loita Maasai: Towards community management of the forest of the lost child - experiences from the Loita ethnobotany project. People and Plants working paper 8. UNESCO, Paris, France.
Morrison, B.J., M.A. Gold, \& D.O. Lantagne. 1996. Incorporating indigenous knowledge of fodder trees into smallscale silvopastoral systems in Jamaica. Agroforestry Systems 34:101-117.

Nikiema, A. 2005. Agroforestry Parkland Species Diversity: Uses and management in semi-arid West Africa (Burkina Faso). PhD Thesis, University of Wageningen, Wageningen, The Netherlands.

Peyre de Fabregues, B. 1977. Lexique de Noms Vernaculaires de Plantes du Niger. Institut d'Elevage et de Medecine Veterinaire des Pays Tropicaux. Alfort, France.

Phillips, O. \& A.H. Gentry. 1993a. The useful plants of Tambopata, Peru: I. Statistical hypothesis tests with a new quantitative technique. Economic Botany 47:15-32.

Phillips, O. \& A.H. Gentry. 1993b. The useful plants of Tambopata, Peru: II. Additional hypothesis testing in quantitative ethnobotany. Economic Botany 47:33-43.

Ricker, I. 2002. Legume Diversity and Ethnobotanical Surveys in the Northern Guinea Savannah of Nigeria. M.S. Thesis, University of Hohenheim, Stuttgart, Germany.

SAS. 1987. Statistical Analysis System. SAS Institute, Cary, North Carolina.

Theilade, I., H.H. Hansen, M. Krog \& C.K. Ruffo. 2007. Use-values and relative importance of trees to the Kaguru people in semi-arid Tanzania: Part II. Woodland species. Forests, Trees and Livelihoods 17:1-15.

Thorne, P.J., D.B. Subba, D.H. Walker, B. Thapa, C.D. Wood \& F.L. Sinclair. 1999. The basis of indigenous knowledge of tree fodder quality and its implications for improving the use of tree fodder in developing countries. Animal Feed Science and Technology 81:119-131.

Turner, M.D. \& P. Hiernaux P. 2002. The use of herders' accounts to map livestock activities across agropastoral landscapes in Semi-Arid Africa. Landscape Ecology 17:367-385.

Vennemann, K. 2000. The population of Niger - distribution and development. Pp. 83-88 in Adapted Farming in West Africa: Issues, potentials and perspectives. Edited by F. Graef., P. Lawrence \& M. von Oppen. Verlag Ulrich, Stuttgart, Germany. 